Ambiente \& Água - An Interdisciplinary Journal of Applied Science
ISSN 1980-993X - doi:10.4136/1980-993X
www.ambi-agua.net
E-mail: ambi.agua@gmail.com

\title{
The importance of climate scenarios in setting the productivity indexes in the Pampa Arenosa sub-region of the province of Buenos Aires, Argentina
}

\author{
ARTICLES doi:10.4136/ambi-agua.2286 \\ Received: 04 Jun. 2018; Accepted: 18 Dec. 2018 \\ Silvia Patricia Pérez ${ }^{1 *}$; Julieta Irigoin ${ }^{2}$; \\ Mariano Tomás Cassani ${ }^{3}$; ; Marcelo Juan Massobrio $^{3}$ (id \\ ${ }^{1}$ Universidad de Buenos Aires (UBA), Buenos Aires, Argentina \\ Facultad de Agronomía (FAUBA). Departamento de Recursos Naturales y Ambiente. \\ E-mail: perezgrima@gmail.com \\ ${ }^{2}$ Instituto Nacional de Tecnología Agropecuaria (INTA), Hurlinghan, Buenos Aires, Argentina \\ Instituto de Suelos (IS). E-mail: irigoin.julieta@inta.gob.ar \\ ${ }^{3}$ Universidad de Buenos Aires (UBA), Buenos Aires, Argentina \\ Facultad de Agronomía (FAUBA). Departamento de Ingeniería Agrícola y Uso de la Tierra. \\ E-mail: mcassani@agro.uba.ar, massobri@agro.uba.ar \\ *Corresponding author
}

\begin{abstract}
Starting in the 1970's, the Pampa Arenosa sub-region experienced an increasing water regime that generated an increased area for dryland farming. With increasing agricultural activity, examining the land is an essential strategic tool for its planning. The objective of this work was to highlight the importance of considering several climate scenarios when setting the productivity index in the sector of longitudinal dunes in the Pampa Arenosa sub-region in the province of Buenos Aires, Argentina. The climate scenarios were set in relation to the shifts in average rain values, according to the Pettitt Test. The land were classified according to their productivity index. It was found that the productivity index of the land increased with the rain, reaching its highest value in the period right after the abrupt shift. Land of moderate productive capacity whose productivity index values are between 65 and 51 comprised the majority of the area of our study.
\end{abstract}

Keywords: agro climatology, land evaluation, Pettitt test, rainfall.

\section{Importância dos cenários climáticos na determinação de índices de produtividade na sub-região Pampa Arenosa da província de Buenos Aires, Argentina}

\section{RESUMO}

A partir da década de 70, a sub-região Pampa Arenosa experimentou um aumento no seu regime de água, o que permitiu o crescimento da área dedicada à agricultura de secas. Em vista da intensificação da atividade agrícola, uma avaliação da terra é uma ferramenta estratégica essencial para o planejamento. O objetivo do trabalho foi destacar a importância de considerar diferentes cenários climáticos, na determinação do Índice de Produtividade, no setor de dunas longitudinais da sub-região Pampa Arenosa na Província de Buenos Aires, Argentina. Os 
cenários climáticos foram estabelecidos de acordo com as mudanças nos valores médios de precipitação, pelo teste Pettitt. As terras foram classificadas pelo índice de produtividade. Verificou-se que o índice de produtividade do solo aumentou com o aumento da precipitação, atingindo sua máxima expressão climática no período após a mudança abrupta. As terras de capacidade produtiva moderada com valores de Índice de Produtividade entre 65-51 ocuparam a maior área da área de estudo.

Palavras-chave: agroclimatologia, avaliação da terra, precipitação, teste de Pettitt.

\section{INTRODUCTION}

The Pampa region, located in the east-central part of the country $\left(30^{\circ} \mathrm{S}-40^{\circ} \mathrm{S}\right.$ y $56^{\circ} \mathrm{O}-$ $65^{\circ} \mathrm{O}$ ), is Argentina's main agricultural area. The Pampa Region has a humid temperate climate (Cf in the Köppen-Geiger classification, as revised by Kottek et al., 2006). East winds predominate, driven by a semi-permanent anticyclone from the coast of Brazil. After being drawn across the Brazilian coastline, maritime subtropical air moves southeast, reaching up to $40^{\circ}$ latitude in summer and about $30^{\circ}$ latitude in winter. In this way, the Pampa Region receives sea winds throughout the year, with a moisture gradient decreasing from east to west (Pérez et al., 2015).

Several studies indicate that the westward advance of the agricultural frontier in the Pampas during the last quarter of the twentieth century (Viglizzo et al., 1995) was partly a consequence of increased rainfall (Castañeda and Barros 1994; Pérez et al., 2011; 2015; Pérez and Sierra 2012). This increase in precipitation acted synergistically with an increasing demand from international markets (Trigo, 2005) and technological innovations (Satorre, 2005).

Some authors believe that the above-mentioned increase in rainfall is permanent. They attribute it to increased energy in the climate system caused by global warming. In their view, this has led to an increased thermal regime throughout the country, affecting the whole of its climate (Carril et al., 1997; Minetti et al., 2003; Barros, 2004). In contrast, others (Suriano and Ferpozzi, 1993; Roberto et al., 1994; Pérez et al., 2003; 2011; Sierra and Pérez, 2006, Pérez et $a l ., 2015)$ suggest that these changes are reversible. In their view, the Pampas have a long-term water cycle with wet and dry phases separated by transition periods during which the agricultural frontier either advances or retreats.

Starting in the 1970's, the Pampa Arenosa sub-region experienced an increasing water regime that generated an increasing area for dryland farming.

With increasing agricultural activity, examining the land becomes an essential strategic tool for its planning.

Several methods are used when creating land evaluation systems in terms of adaptability and/or vulnerability (De la Rosa et al., 2004). In Argentina, the most frequent quantitative indirect classification is the productivity index (PI). This system was developed initially by FAO (Riquier et al., 1970) and adopted by the National Institute of Agricultural Technology (in Spanish, Instituto Nacional de Tecnología Agropecuaria) according to the local agroecological conditions. The productivity index relates the property values or levels that have some influence on land productivity (Irigoin, 2011).

The objective of this work was to highlight the importance of considering several climate scenarios when setting the productivity index in the sector of longitudinal dunes in the Pampa Arenosa sub-region in the province of Buenos Aires, Argentina. 


\section{MATERIAL AND METHODS}

The area of study comprises the second-level administrative subdivisions of Nueve de Julio, Carlos Casares, Pehuajó and Trenque Lauquen, which are located in the province of Buenos Aires, Argentina, in the sector of longitudinal dunes of the Pampa Arenosa sub-region. Annual rainfall data from four towns in the Pampa Arenosa sub-region for the period 19182011 was used (Table 1). Data was provided by the National Weather Service and the National Institute of Agricultural Technology.

The homogeneity of the precipitation series was tested using Alexandersson and Moberg's (1997) Standard Normal Homogeneity Test (SNHT) on AnClim software (Štěpánek, 2006). The test was applied to series of annual values, using the average annual rainfall of each subregion as a reference series.

Table 1. Locations of towns in the Pampa Arenosa sub-region.

\begin{tabular}{lccc}
\hline Town/City & Latitude $(\mathbf{S})$ & Longitude $(\mathbf{W})$ & Altitude $(\mathbf{m s l})$ \\
\hline Nueve de Julio & $35^{\circ} 27^{\prime}$ & $60^{\circ} 53^{\prime}$ & 76 \\
Carlos Casares & $35^{\circ} 55^{\prime}$ & $61^{\circ} 20^{\prime}$ & 88 \\
Pehuajó & $35^{\circ} 48^{\prime}$ & $61^{\circ} 54^{\prime}$ & 85 \\
Trenque Lauquen & $35^{\circ} 58^{\prime}$ & $62^{\circ} 43^{\prime}$ & 80 \\
\hline
\end{tabular}

With the homogeneous precipitation series of each town, shifts in the average values were found using the Pettitt test. The climate scenarios were defined using the temporal series of rainfall for the periods before and after the shifts in the average values, identified as the dry period (DP) and the humid period (HP), respectively.

The productivity index (PI) was obtained by using the changes introduced by the National Institute of Agricultural Technology (INTA) for the Pampa region (Sobral and Nakama 1988; Maccarini, 1990; Sobral et al., 2010). This parametric index comprises the following factors: Macro-climate condition (H); drain (D); effective depth (Pe); surface texture (Ta); sub-surface texture $(\mathrm{Tb})$; salinity $(\mathrm{Sa})$; sodicity $(\mathrm{Na})$; organic matter $(\mathrm{Mo})$; cation-exchange capacity $(\mathrm{T})$, current and potential water and wind erosion (E).

The quantitative expression of the productivity index is calculated by multiplying the factors listed above. This multiplication intends to highlight the influence of each factor on the final value of the index (Equation 1):

$$
\mathbf{P I}=\mathbf{H} * \mathbf{D} * \mathbf{P e} * \mathbf{T a} * \mathbf{T b} * \mathbf{S a} * \mathbf{N a} * \mathbf{M o} * \mathbf{T} * \mathbf{E},
$$

The results of the PI calculation are positive values, the highest of which is equal to 100, where the highest value represents the greater productive capacity of the land.

\subsection{Climate factor of the PI}

The climate factor $\mathrm{H}$ of the PI was calculated following the INTA methodology (Sobral and Nakama 1988; Maccarini, 1990).

The climate factor was calculated using Thornthwaite's global humidity index (Im), the soil moisture regimes (Moscatelli, 1991; Van Wambeke and Scoppa, 1980) and the $16^{\circ} \mathrm{C}$ isotherm (Table 2).

El Im (Thornthwaite, 1948; 1955) was obtained from the difference between the annual water excess (humidity index, Ih) and the deficiencies (aridity index, Ia) as the result of the water balance for maximum water storage capacity in soil of $100 \mathrm{~mm}$ and its relation with the potential evapotranspiration (ETP) estimated by Thornthwaite, where $\mathrm{Im}=(\mathrm{Ih}-\mathrm{Ia}) / \mathrm{ETP}$

\section{IPABH}

Rev. Ambient. Água vol. 14 n. 2, e2286 - Taubaté 2019 
(Castellví Sentí and Castillo, 2001). The value for Im for the area as a whole was obtained from the average of the value for Im for each area.

Table 2. Conversion of climate characteristics into coefficient $\mathrm{H}$ values (Macroclimate condition) (Maccarini 1990).

\begin{tabular}{ccc}
\hline $\begin{array}{c}\text { Global humidity index } \\
(\mathbf{I m})\end{array}$ & $\begin{array}{c}\text { Average annual temperature } \\
\left({ }^{\circ} \mathbf{C}\right)\end{array}$ & $\begin{array}{c}\text { Macro-climate condition } \\
(\mathbf{H})\end{array}$ \\
\hline 10 & $\geq 16$ & 100 \\
10 to 0 & $\geq 16$ & 95 \\
0 to -10 & $\geq 16$ & 90 \\
-10 at ustic/aridic & $\geq 16$ & 75 \\
\hline
\end{tabular}

\subsection{Edaphics factors of the PI}

The edaphic information for the different factors that make up the PI is the following: drain, alkalinity, salinity, texture, cation-exchange capacity, content of organic matter, current and potential water and wind erosion. All this data was obtained from soil charts (INTA, 1990).

The PI value was obtained for each taxonomic unit defined at a series level, from the use of conversion tables (Irigoin, 2011), where each edaphic factor participating in the parametric equation is classified into categories or ranges with their respective coefficients with values between 0 and 1 (Sobral et al., 2010, Sobral and Nakama, 1988).

The PI value of the cartographic unit was calculated by weighing the PI values of each taxonomic unit and in relation to the percentage of area covered by each of them.

The PI values of the cartographic units were divided into six productive categories: very high (>80), high (80-66), moderate (65-51), moderately low (50-36), low (35-20) and very low (<20) (Irigoin, 2011).

\section{RESULTS AND DISCUSSION}

\subsection{Homogeneity Test}

According to the Homogeneity Test (SNHT), two of the annual precipitation series available (Table 3) showed a T value lower than the critical value (Khaliq and Quarda, 2007), and can be considered homogeneous at the level of significance $\alpha=0.05$. The other two series showed $\mathrm{T}$ values higher than the critical value and were thus considered non-homogeneous. For the analysis, the non-homogeneous series were adjusted according to the method proposed by Alexandersson (1986).

Table 3. Test results of the SNHT applied to annual precipitation series for the Pampa Arenosa sub-region.

\begin{tabular}{lcccc}
\hline Town/City & Shift year & T Value & Adjusted shift year & Adjusted T value \\
\hline Nueve de Julio & 1984 & 7.107 & & \\
Carlos Casares & 2010 & 4.157 & & \\
Pehuajo & 1935 & $10.747 *$ & 1954 & 2.191 \\
Trenque Lauquen & 1972 & $14.080 *$ & 2010 & 4.647 \\
\hline
\end{tabular}

(* indicates that the $\mathrm{T}$ value exceeds $95 \%$ ).

\subsection{Pettitt Test}

The shifts in the values of the annual precipitation average according to the Pettitt Test (Pettitt, 1979) (Table 4) were produced in 1962 and 1965, thus defining the dry scenarios, before the shift (1918-1962/65) and wet, after the shift (1962/65-2005). 
Table 4. Results after the Pettitt Test for the annual precipitation of the Pampa Arenosa subregion.

\begin{tabular}{lccc}
\hline Town/City & Shift year & $\begin{array}{c}\text { Average annual rainfall (mm) } \\
\text { Before the shift }\end{array}$ & $\begin{array}{c}\text { Rainfall increase (\%) } \\
\text { After the shift }\end{array}$ \\
\hline Nueve de Julio & 1962 & 893 & 16.8 \\
Carlos Casares & 1965 & 787 & 22.5 \\
Pehuajo & 1965 & 820 & 19.3 \\
Trenque Lauquen & 1962 & 708 & 38.3 \\
\hline
\end{tabular}

The average of Nueve de Julio (Figure 1) showed a positive abrupt change, with the average annual precipitation rising from $893 \mathrm{~mm}$ during the 1918-1962 sub-period, to $1043 \mathrm{~mm}$ during the 1963-2011 sub-period.

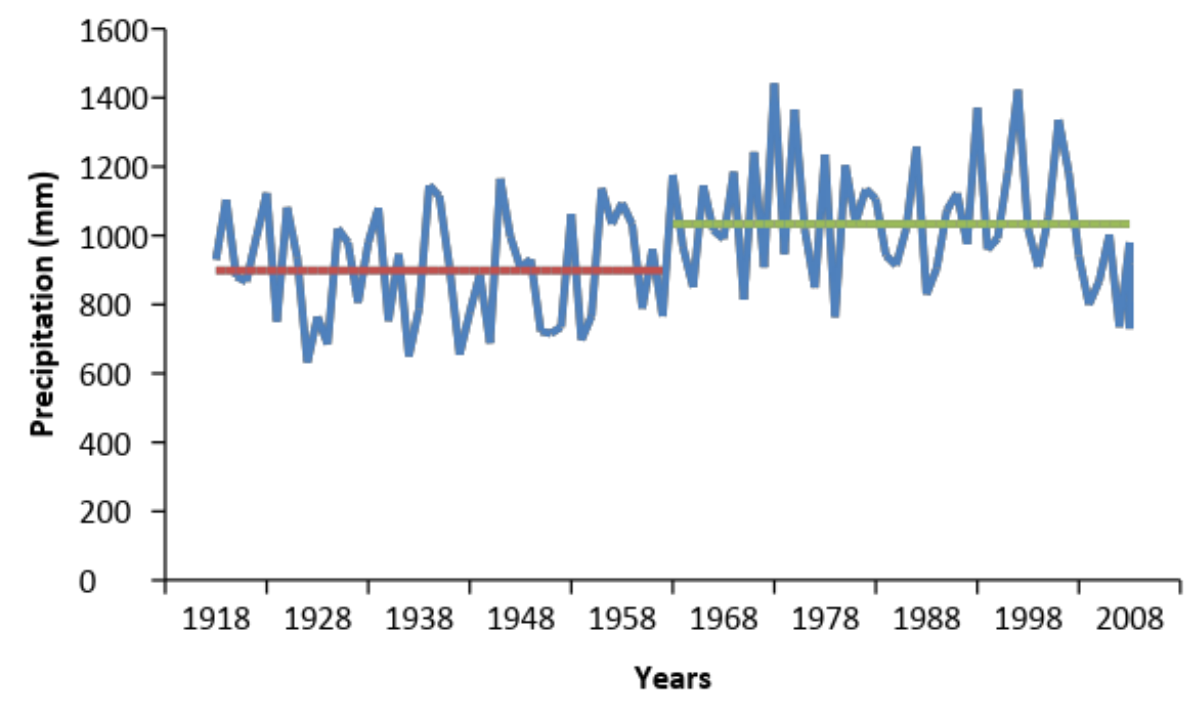

Figure 1. Annual precipitation and means for sub-periods in the Nueve de Julio by Pettitt's method.

The average of Carlos Casares (Figure 2) showed a positive abrupt change, with the average annual precipitation rising from $787 \mathrm{~mm}$ during the 1918-1965 sub-period, to $964 \mathrm{~mm}$ during the 1966-2011 sub-period.

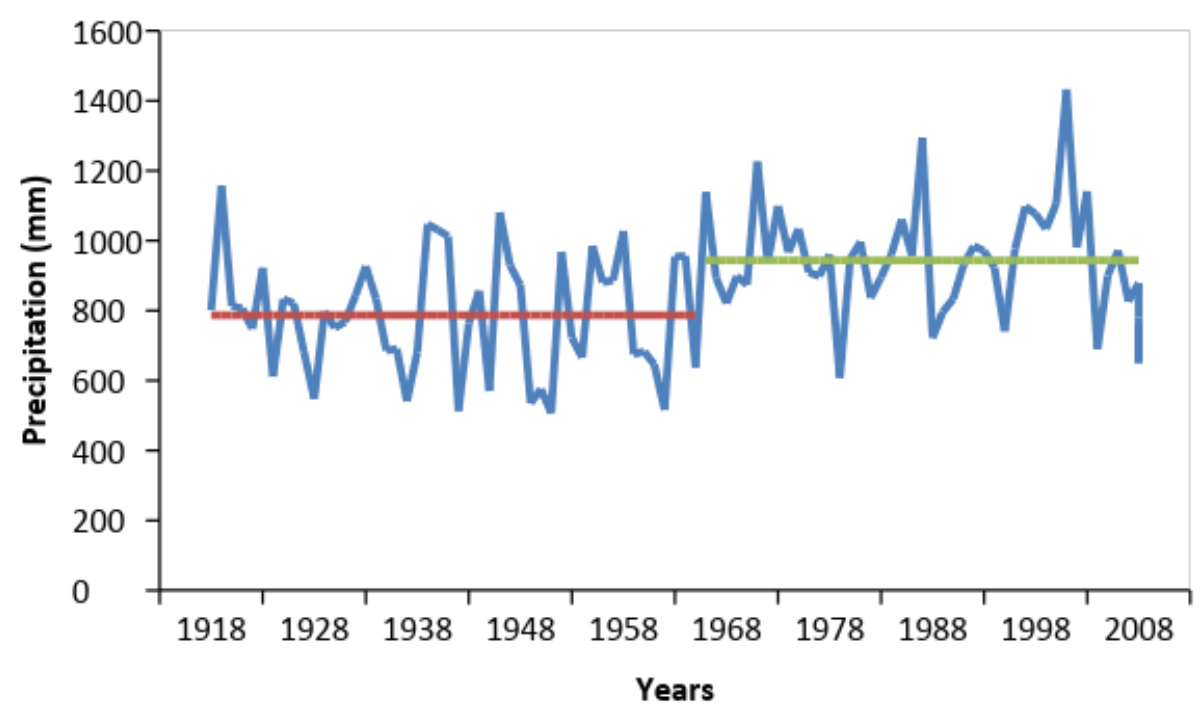

Figure 2. Annual precipitation and means for sub-periods in the Carlos Casares by Pettitt's method.

\section{IPABH}

Rev. Ambient. Água vol. 14 n. 2, e2286 - Taubaté 2019 
The average of Pehuajo (Figure 3) showed a positive abrupt change, with the average annual precipitation rising from $820 \mathrm{~mm}$ during the 1918-1965 sub-period, to $978.2 \mathrm{~mm}$ during the 1966-2011 sub-period.

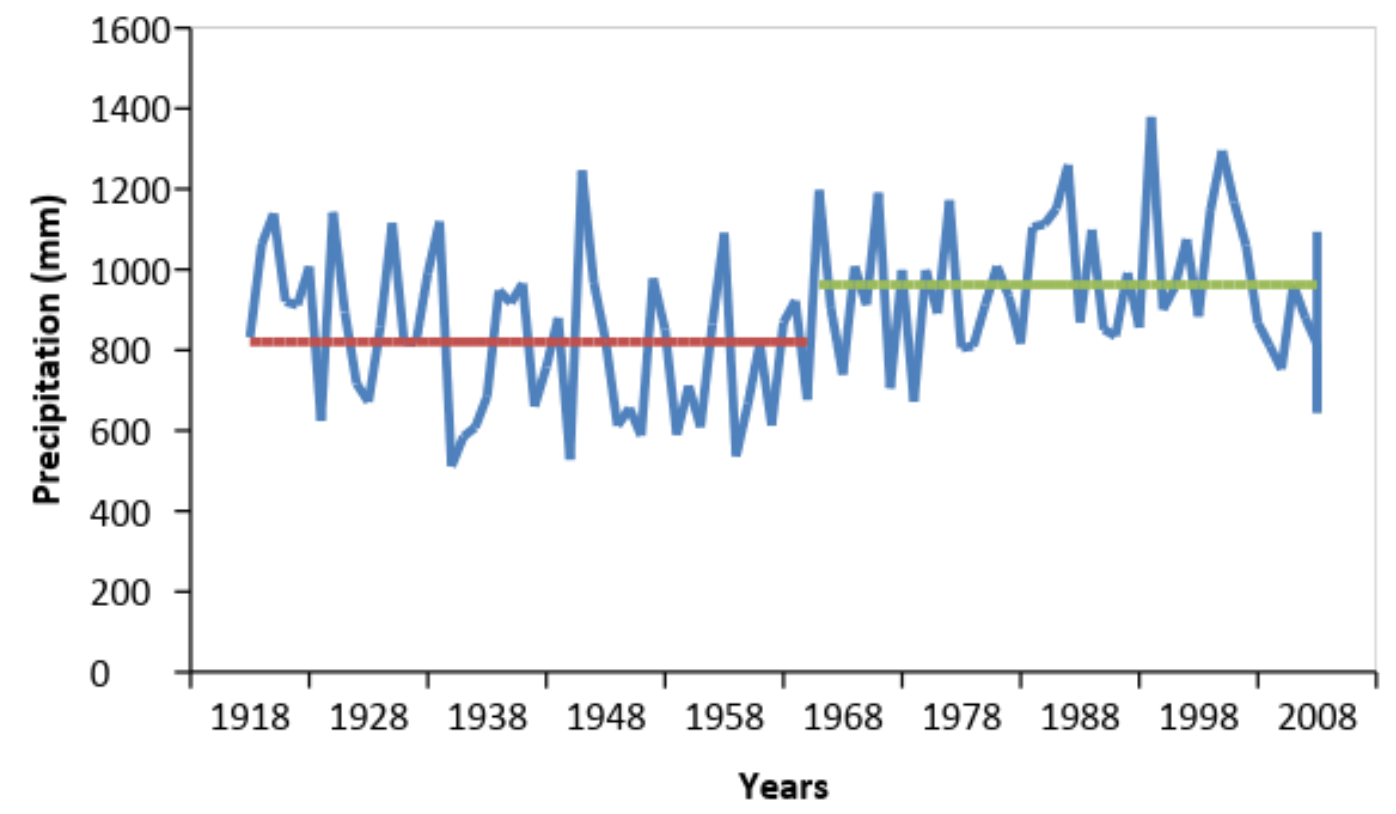

Figure 3. Annual precipitation and means for sub-periods in the Pehuajo by Pettitt's method

The average of Trenque Lauquen (Figure 4) showed a positive abrupt change, with the average annual precipitation rising from $708 \mathrm{~mm}$ during the 1918-1962 sub-period, to $979.2 \mathrm{~mm}$ during the 1963-2011 sub-period.

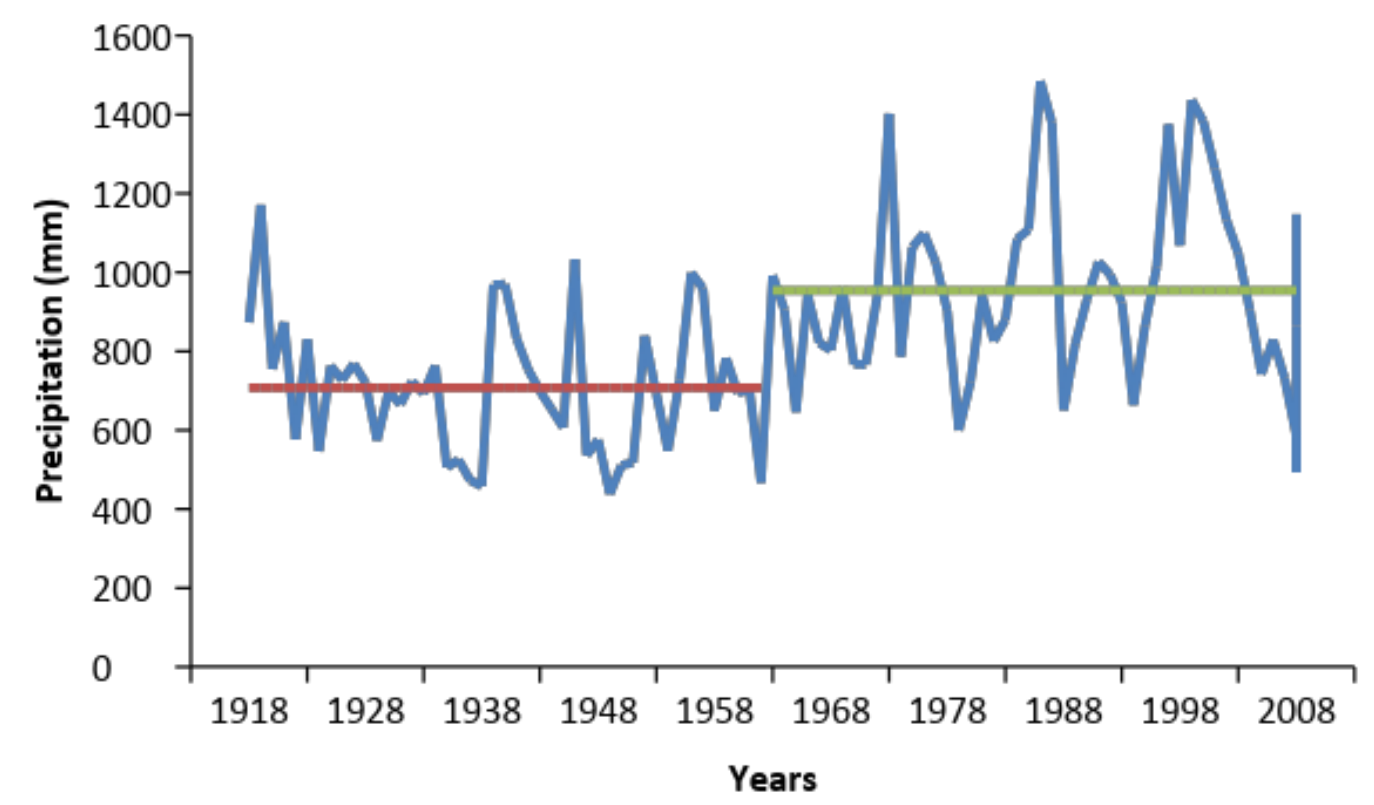

Figure 4. Annual precipitation and means for sub-periods in the Trenque Lauquen by Pettitt's method.

\subsection{Productivity Index}

Table 5 shows the productivity indices in the sector of longitudinal dunes in the Pampa Arenosa sub-region in the province of Buenos Aires, Argentina. In the study area, 
approximately 458,700 hectares have values of productivity index between 65 and 51, indicating that these lands have some type of permanent limitations for the production of common crops. On the other hand, these IP values would indicate that the feasible yield to obtain will correspond between 65 and $50 \%$ of the optimum yield for the region (Sobral and Nakama, 1988). A similar area (460,720 hectares) corresponds to lands of moderately low productive capacity with IP values of 50-36. These two IP categories represent more than half of the study area, approximately $54.7 \%$. At the same time, lands with severe and very severe limitations for agriculture occupy 668,320 hectares with IP values of less than 35 .

Table 5. Classification of the lands according to the Productivity Index (PI) for the study area and for each Town/City, expressed in \% of occupation and $\mathrm{km}^{2}$.

\begin{tabular}{lccccccc}
\hline & & \multicolumn{7}{c}{ Productivity Index (PI) } \\
\hline Town/City & Occupation & $\mathbf{1 0 0 - 8 1}$ & $\mathbf{8 0 - 6 6}$ & $\mathbf{6 5 - 5 1}$ & $\mathbf{5 0 - 3 6}$ & $\mathbf{3 5 - 2 1}$ & $\mathbf{2 0 - 0}$ \\
Nueve de Julio & $\mathbf{k m}^{\mathbf{2}}$ & 88.5 & 623.1 & 1717.8 & 215.2 & 1026.2 & 614.9 \\
& $\mathbf{\%}$ & 2.1 & 14.5 & $\mathbf{4 0 . 1}$ & 5.0 & 23.9 & 14.4 \\
Carlos Casares & $\mathbf{k m}^{\mathbf{2}}$ & 0.0 & 200.0 & 830.4 & 28.3 & 943.5 & 516.5 \\
& $\mathbf{\%}^{2}$ & 0.0 & 7.9 & $\mathbf{3 3 . 0}$ & 1.1 & 37.5 & 20.5 \\
Pehuajó & $\mathbf{k m}^{2}$ & 0.0 & 3.4 & 1312.6 & 1381.7 & 740.6 & 1081.8 \\
& $\mathbf{\%}_{\text {Trenque Lauquen }}$ & 0.0 & 0.1 & $\mathbf{2 9 . 0}$ & $\mathbf{3 0 . 6}$ & 16.4 & 23.9 \\
& $\mathbf{k m}^{2}$ & 0.0 & 0.0 & 726.2 & 2982.0 & 1340.1 & 419.6 \\
Study area & $\mathbf{\%}^{\mathbf{2}}$ & 0.0 & 0.0 & 13.3 & $\mathbf{5 4 . 5}$ & 24.5 & 7.7 \\
& $\mathbf{k m}^{2}$ & 88.5 & 826.5 & 4587.0 & 4607.2 & 4050.4 & 2632.8 \\
& $\mathbf{\%}$ & 0.5 & 4.8 & $\mathbf{2 7 . 3}$ & $\mathbf{2 7 . 4}$ & 24.1 & 15.7 \\
\hline
\end{tabular}

According to the PI values for both climate scenarios and their location, we can observe a shift in the productivity of the land as the consequence of shifts in the climate factor.

The PI weighted average obtained for the period right after the abrupt shift for the Nueve de Julio area was 48.5, for Carlos Casares was 43.7, for Pehuajó was 39.9 and for Trenque Lauquen was 46.1 (Figure 5). On the other hand, the PI values for the period before were 39.4, $36.1,36.9$ and 34.4 , respectively, according to the transect of these areas, from East to West (Figure 6).

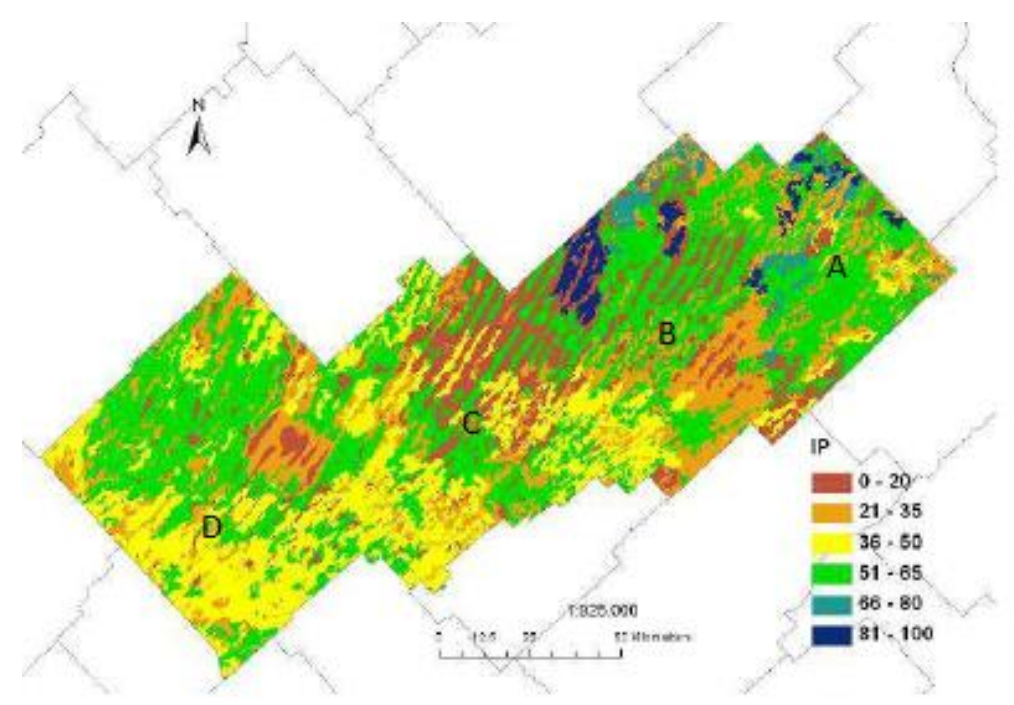

Figure 5. Distribution pattern of the classes of productivity index of the land (PI) for the period after the abrupt shift in the area of Nueve de Julio (A), Carlos Casares (B), Pehuajó (C) and Trenque Lauquen (D). 


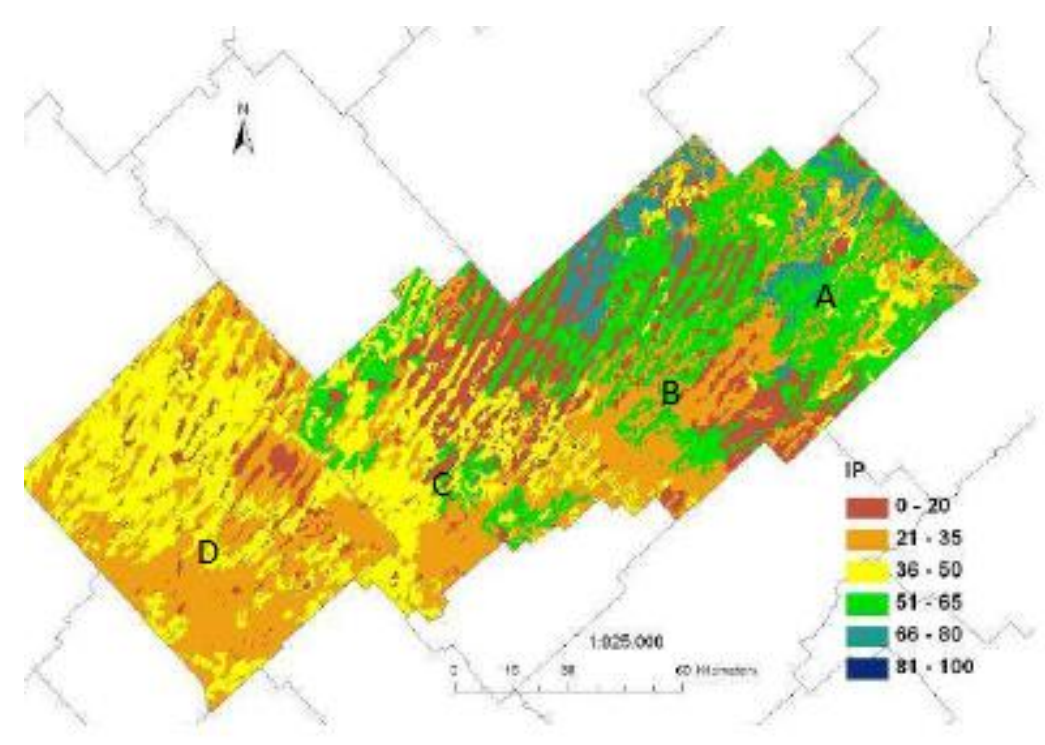

Figure 6. Distribution pattern of the classes of productivity index of the land (PI) for the period before the abrupt shift in the area of Nueve de Julio (A), Carlos Casares (B), Pehuajó (C) and Trenque Lauquen (D).

In this way, the land resulted of moderately low productive capacity (50-36), both for the period after the abrupt shift and for the period before, thus showing that such land has permanent edaphic limitations for the production of conventional crops. The productivity index is interpreted as a proportion of the potential maximum yield of the most common crops in the region, eco-typically adapted, under a determined level of management.

\section{CONCLUSION}

The Pettitt Test (Pettitt, 1979), applied to the annual precipitation series of the Pampa Arenosa sub-region, showed that the sub-region had abrupt positive shifts during the second half of the $20^{\text {th }}$ century. This sub-region was considerably affected by such shifts. Indeed, they changed from a semi-arid steppe climate (Bs in the Köppen Climate Classification System) (Köppen, 1948) during dry phases to a dry-summer subtropical climate $(\mathrm{CW}$ in the Köppen classification) during wet phases, which significantly affects agricultural capacity.

It was found that the PI of the lands increased with the rain, reaching its highest value in the period right after the abrupt shift for all the studied areas. The Trenque Lauquen area was the area most positively affected by increasing precipitation.

\section{REFERENCES}

ALEXANDERSSON, H. A homogeneity test applied to precipitation data. International $\begin{array}{lllllllll}\text { Journal of Climatology, v. } 6, \quad \text { n. } & 6, & \text { p. } & 661-675, & 1986 .\end{array}$ https://doi.org/10.1002/joc.3370060607

ALEXANDERSSON, H.; MOBERG, A. Homogenization of Swedish temperature data. Part I: homogeneity test for linear trends. International Journal of Climatology v. 17, p. 2534, 1997. https://doi.org/10.1002/(SICI)1097-0088(199701)17:1\%3C25::AIDJOC103\%3E3.0.CO;2-J

BARROS, V. El cambio climático global. [S.1.]: Del Zorzal, 2004. 
CARRIL, A. F.; MENÉNDEZ, C. G.; NUÑEZ, M. M. Climate change scenarios over the South American region: an intercomparison of coupled general atmosphere-ocean circulation models. International Journal of Climatology, v. 17, n. 15, p. 1613-1633, 1997. https://doi.org/10.1002/(SICI)1097-0088(199712)17:15\%3C1613::AIDJOC209\%3E3.0.CO;2-8

CASTAÑEDA, M. E.; BARROS, V. Las tendencias de la precipitación en el Cono Sur de América al este de los Andes. Meteorológica, v. 19, n. 1-2, p. 23-32, 1994.

CASTELlVÍ SENTÍS, F.; CASTILlO, F. Agrometeorología. [S.1.]: Mundi-Prensa, 2001, 517 p.

DE LA ROSA, D.; MAYOL, F.; DÍAZ-PEREIRA, E.; FERNÁNDEZ, M.; DE LA ROSA, D. J. R. A land evaluation decision support system (MicroLEIS DSS) for agricultural soil protection with special reference to Mediterranen region. Environmental Modelling \& Sofware, v. 19, p. 929-942, 2004. https://doi.org/10.1016/j.envsoft.2003.10.006

INTA. Atlas de Suelos de la República Argentina. Escala 1: 500.000 y 1: 1.000.000. Tomo I y II. Proyecto PNUD ARG. 85/019. Ed. INTA, Buenos Aires Argentina. 1990, 667 p.

IRIGOIN, J. Sistemas de evaluación de tierras y elaboración de modelos de aptitud de uso agrícola, para distintos escenarios climáticos, en un sector de la subregión Pampa Arenosa (Provincia de Buenos Aires, Argentina). 2011. 160 p. Tesis (Maestría de Agronomía) - Universidad de Buenos Aires, Buenos Aires, 2011. 160 p.

KHALIQ, M. N.; QUARDA, T. B. M. J. On the critical values on the standard normal homogeneity test (SNHT). International Journal of Climatology, v. 27, p. 681-687, 2007. https://doi.org/10.1002/joc.1438

KÖPPEN, W. Climatología. Mexico: Fondo de Cultura Económica, 1948. 478 p.

KOTTEK, M.; GRIESER, J.; BECK, C.; RUDOLF, B.; RUBEL, F. World Map of the KöppenGeiger climate classification updated. Meteorologische Zeitschrift, v. 15, n. 3, p. 259263, 2006. https://doi.org/10.1127/0941-2948/2006/0130

MACCARINI, G. D. Utilización del Método de evaluación de tierras paramétrico de Bramao y Riquier y su adaptación por INTA en un sector de la Región Pampeana Húmeda. 1990. Tesis (Maestría en Ciencias del Suelo) - Escuela de Posgrado, Facultad de Agronomía, Universidad de Buenos Aires, Buenos Aires,1990.

MINETTI, J. L.; VARGAS, W. M.; POBLETE, A. G.; ACUNA, L. G.; CASAGRANDE, G. Non-linear trends and low frequency oscillations in annual precipitation over Argentina and Chile, 1931- 1999. Atmosfera, v. 16, p. 119-135, 2003.

MOSCATELLI, G. Los suelos de la Región Pampeana. In: BARSKY, O. (Ed.). EI desarrollo agropecuario pampeano. Buenos Aires: INDEC-INTA-IICA, 1991. p. 1-76.

PÉREZ, S.; SIERRA, E. M.; CASAGRANDE, G.; VERGARA, G.; BERNAL, F. Comportamiento de las precipitaciones (1918/2000) en el centro oeste de la provincia de Buenos Aires (Argentina). Revista De la Facultad de Agronomía de la Universidad Nacional de La Pampa, v. 14, n. 1-2, p. 39-46, 2003.

PÉREZ, S.; SIERRA, E.; LÓPEZ, E.; NIZZERO, G.; MOMO, F.; MASSOBRIO, M. Abrupt changes in rainfall in the Eastern area of La Pampa Province, Argentina. Theoretical and Applied Climatology, v. 103, p. 159-165, 2011. https://doi.org/10.1007/s00704-0100290-y 
PÉREZ, S.; SIERRA, E. Changes in rainfall patterns in the eastern area of La Pampa province, Argentina. Revista Ambiente \& Agua, v. 7, n. 1, p. 24-35, 2012. http://dx.doi.org/10.4136/ambi-agua.692

PÉREZ, S.; SIERRA, E.; MOMO, F.; MASSOBRIO, M. Changes in Average Annual Precipitation in Argentina's Pampa Region and Their Possible Causes. Climate, v. 3, p. 150-167, 2015. http://d.doi.org/10.3390/cli3010150

PETTITT, A. N. A non-parametric approach to the change point problem. Applied Statistics, v. 28 , n. 2, p. 126-135, 1979. http://dx.doi.org/10.2307/2346729

RIQUIER, J.; BRAMAO, L.; CORNET, S. P. A new system of soil appraisal in terms of actual and potential productivity. Roma: FAO, 1970.

ROBERTO, Z. E.; CASAGRANDE, G.; VIGLIZZO, E. Lluvias en la Pampa Central: tendencia y variaciones del siglo. Cambio Climático y Agricultura Sustentable en la Región Pampeana. Boletine INTA Centro Regional La Pampa-San Luis, n. 2, 1994.

SATORRE, E. H. Cambios tecnológicos en la agricultura argentina actual. Ciencia Hoy, v. 15, n. 87, p. 24-31, 2005.

SIERRA, E. M.; PÉREZ, S. P. Tendencia del régimen de precipitación y el manejo sustentable de los agroecosistemas: estudio de un caso en el noroeste de la provincia de Buenos Aires, Argentina. Revista de Climatología, v. 6, p. 1-12, 2006.

SOBRAL, R. E.; NAKAMA, V. Índices de productividad, método paramétrico para evaluación de tierras. In: CONGRESO ARGENTINO DE LA CIENCIA DEL SUELO, 12., 12 al 16 septiembre 1988, Corrientes. Actas [...] [S.1.]: Comisión mineralogía, génesis, clasificación y cartografía de suelos, 1988. 259 p.

SOBRAL, R. E.; NAKAMA , V.; DE ANTUENO, L. Actualización de los índices de productividad de los suelos de la provincia de Buenos Aires. In: CONGRESO ARGENTINO DE LA CIENCIA DEL SUELO, 22., 31 de mayo al 4 de Junio 2010, Rosario, Argentina. Actas [...] [S.1.]: Comisión mineralogía, génesis, clasificación y cartografía de suelos, 2010.

SURIANO, J. M.; FERPOZZI, L. H. Los cambios climáticos en la Pampa también son historia. Todo es Historia, n. 306, p. 8-25, 1993.

ŠTĔPÁNEK, P. AnClim Software for time series analysis. Masaryk: Masaryk University, 2006.

THORNTHWAITE, C. W. An approach toward a rational classification of climate. The Geografical Review, v. 38, p. 55-94, 1948. http://dx.doi.org/10.2307/210739

THORNTHWAITE, C. W; HARE, F. K. Climate classification in Forestry. Unasylva, v. 9, n. $2,1955$.

TRIGO, E. Consecuencias económicas de la transformación agrícola. Ciencia Hoy, v. 15, n. 87, p. 46-51, 2005.

VAN WAMBEKE, A.; SCOPPA, C. Las taxas climáticas de los suelos argentinos. Castelar: Intacirn, 1980.

VIGLIZZO, E. F.; ROBERTO, Z. E.; FILIPPIN, M. C.; PORDOMINGO, A. J. Climate variability and agroecological change in the Central Pampas of Argentina. Agriculture Ecosystems and Environment, v. 55, p. 7-16, 1995. https://doi.org/10.1016/01678809(95)00608-U 